\title{
Effects of precommercial thinning on the forest value chain in northwestern New Brunswick: Part 6 - Estimating the economic benefits
}

\author{
by Doug Pitt ${ }^{1, *}$ Len Lanteigne ${ }^{2}$, Michael K. Hoepting ${ }^{1}$, Jean Plamondon ${ }^{3}$, Isabelle Duchesne ${ }^{4}$, \\ Paul Bicho ${ }^{5}$ and Gary Warren ${ }^{6}$
}

\begin{abstract}
The Green River precommercial thinning (PCT) trials were established between 1959 and 1961 in naturally regenerating balsam fir (Abies balsamea [L.] Mill.)-dominated stands an average of eight years after overstory removal. Following clearcut harvest of three of the study's six replicates in the fall of 2008, the rotation-length effects of PCT and vegetation management (VM; deciduous tree and brush suppression) on the forest value chain were integrated into a spreadsheet-based model that estimates the net present value (NPV) of these silvicultural treatments. Assuming costs and prices near recent values, both PCT and VM were observed to support positive landowner NPVs through discount rates in excess of $6 \%$. At a discount rate of $4 \%$ and an age where sawlog production was maximized, PCT and VM offered similar NPV $(>\$ 550 / \mathrm{ha})$. Landowners that can attract buyers willing to pay a premium for wood from thinned stands (equal to the sum of reduced operational overhead charges, harvesting and sawmilling costs and increased pulping costs) could see the value of their stands double. Sensitivity analyses revealed that these results are dependent on site productivity, silvicultural costs and a strong premium on sawlog stumpage rates. Depending on economic circumstances, PCT and VM could be attractive investments on high quality sites that are situated in close proximity to wood processing infrastructure.
\end{abstract}

Keywords: silviculture, precommercial thinning, vegetation management, balsam fir (Abies balsamea), net present value (NPV)

\section{RÉSUMÉ}

Les essais déclaircie précommerciale de Green River ont été réalisés entre 1959 et 1961 dans des peuplements naturellement régénérés de sapin baumier (Abies balsamea [L.] Mill.) et dominés par cette espèce, huit années en moyenne après le retrait de létage dominant. Au cours de lautomne 2008, trois des six répétitions ont été coupées à blanc, les effets de léclaircie précommerciale tout au long de la révolution et le contrôle de la végétation (CV; suppression des feuillus et des broussailles) sur la chaine de valeur forestière ont été intégrés dans un modèle de calcul prédéfini qui estime la valeur actuelle nette (VAN) de ces traitements sylvicoles. En estimant que les coûts et les prix offerts sont proches de leur valeur actuelle, tant léclaircie précommerciale que le CV ont engendré une VAN positive pour les propriétaires sous forme de taux descompte de plus de 6\%. Dans le cas d'un taux descompte de $4 \%$ et d'un âge où la production de billes de sciage est maximisée, léclaircie précommerciale et le $\mathrm{CV}$ ont présenté une VAN similaire (>550 \$/ha). Les propriétaires qui peuvent attirer des acheteurs prêts à payer une prime pour du bois provenant de peuplements éclaircis (égale à la somme des réductions des frais de gestion des opérations, des coûts d'exploitation et de sciage et des frais accrus de mise en pâte) pourrait voir doubler la valeur de leurs peuplements. Les analyses de sensibilité indiquent que ces résultats dépendent de la productivité du site, des coûts des travaux sylvicoles et d'une prime élevée sur les droits de coupe de bois de sciage. Selon les conditions économiques, léclaircie précommerciale et le CV pourraient être des investissements intéressants sur les sites de qualité supérieure qui sont situés à proximité des infrastructures de transformation du bois.

Mots clés : sylviculture, éclaircie précommerciale, contrôle de la végétation, sapin baumier (Abies balsamea), valeur actuelle nette (VAN)

\footnotetext{
${ }^{1}$ Natural Resources Canada, Canadian Forest Service, Canadian Wood Fibre Centre, 1219 Queen St. E., Sault Ste. Marie, Ontario P6A 2 E5.

${ }^{2}$ Natural Resources Canada, Canadian Forest Service, Canadian Wood Fibre Centre, Hugh John Flemming Forestry Centre, P.O. Box 4000, Fredericton, New Brunswick E3B 5P7.

${ }^{3}$ FPInnovations, Forest Operations, 570 St. Jean Blvd., Pointe Claire, Quebec H9R 3J9.

${ }^{4}$ Natural Resources Canada, Canadian Forest Service, Canadian Wood Fibre Centre, 1055, rue du P.E.P.S., P.O. 10380 succ. Sainte-Foy, Québec, Quebec G1V 4C7.

${ }^{5}$ Formerly FPInnovations, 3800 Wesbrook Mall, Vancouver, British Columbia. Now Canfor Pulp Innovation, \#138-8610 Glenlyon Parkway, Burnaby, British Columbia V5J 0B6.

${ }^{6} 122$ MacDonald Brown Dr., Corner Brook NL, Canada. A2H 7N8. Formerly Canadian Forest Service, Canadian Wood Fibre Centre, 26 University Dr., Corner Brook, NL, Canada. A2H 6J3.

*Corresponding author. E-mail: dpitt@NRCan.gc.ca
} 


\section{Introduction}

Precommercial thinning (PCT) is a silvicultural tool that is used to reduce the density of young stands that have developed from prolific natural regeneration or artificial seeding. While PCT may be used in a variety of forest types (Murray and Cameron 1987), its primary application in eastern Canada has been in conifer-dominated forests, where more than 2.7 million hectares have been thinned during the past 20 years and efforts continue at a rate exceeding 100000 ha per year (CCFM 2012).

The intent of PCT is to redistribute available growing resources, including sunlight, soil moisture and nutrients, to selected stems during juvenile stand development, when felled trees are below merchantable size limits (Smith 1986). A variety of well-understood and accepted stand-level management objectives can be achieved with PCT, including control over species composition, increasing the proportion of trees with desirable characteristics, preparation of stand structure for subsequent commercial thinning, and increased tree growth and health (Piene 1982, Smith 1986, Karsh et al. 1994, Smith et al. 1997, Anonymous 2008).

Less understood and accepted by decision-makers are the product yield implications and associated financial returns of PCT; factors that affect forest-level management objectives and decisions over the long term. In the absence of empirical data, managers have been forced to use model projections to conduct optimization and financial analyses of silvicultural inputs including PCT (e.g., Daggett 2003, Olson et al. 2012, Bataineh et al. 2013) and vegetation management (VM) (e.g., Homagain et al. 2011). The outputs of these analyses are necessarily highly dependent on a variety of assumptions, and the absence of rotation-length validation data has contributed to protracted uncertainty and skepticism about the real economic benefits of such silvicultural investments. As we enter an era where slowgrown, natural-origin, conifer-dominated forests account for an increasingly smaller portion of our wood supply, continued lack of clarity about the financial benefits of silviculture may impede sound decision-making around investment in forest renewal and, ultimately, may threaten sustainability of both the forest and the forest industry (Reed 1986).

The Green River PCT trials, established by Dr. Gordon Baskerville in northwestern New Brunswick between 1959 and 1961, offer a statistically rigorous, rotation-length view of the effects of thinning on the growth and yield of balsam fir (Abies balsamea [L.] Mill.)dominated stands (Baskerville 1959, 1961; Akerley 1961; Pitt and Lanteigne 2008; Pitt et al. 2013a). We used harvest data collected some 50 years after thinning to document the component effects of PCT on the forest value chain, including roundwood product yield (Pitt et al. 2013b), harvesting and wood handling efficiencies (Plamondon and Pitt 2013), disease losses (Warren et al. 2013), lumber product yield (Duchesne et al. 2013) and pulp and paper production (Bicho et al. 2013). In the sixth paper of this series, we introduce a spreadsheet-based model (available from the authors upon request) that quantitatively integrates the findings outlined in the previous papers and permits comparisons of the treatment alternatives, given user-defined inputs related to costs and prices. Herein we test the sensitivity of the influence of these inputs on the net present value (NPV) of standing timber, illustrating the use of the rotation-length Green River data in value chain optimization. It is our hope that these data will contribute to a better foundation of understanding about the financial returns available from silvicultural treatments such as PCT in northeastern Canada and the United States, thus promoting sound decision-making around sustainability and investments in forest renewal.

\section{Methods \\ Stand response data}

A detailed description of the Green River experiment can be found in Pitt et al. (2013a). Between 1959 and 1961, three nominal PCT spacings $(4 \mathrm{ft}[1.2 \mathrm{~m}], 6 \mathrm{ft}[1.8 \mathrm{~m}]$ and $8 \mathrm{ft}[2.4 \mathrm{~m}]$ ) were replicated six times within six naturally regenerated balsam firdominated stands, an average of eight years following harvest. Treatment plots were at least 1 ha in size and each contained two 0.081-ha permanent sample plots (PSPs). Each of the six replicate blocks also contained a similarly quantified unthinned control plot. Stands had originated from advanced regeneration that averaged eight years of age at the time of harvest; thus, trees were approximately 16 years old, on average, at the time of thinning (see Table 1 of Pitt et al. 2013b). Site index (dominant tree height at breast-height age 50) ranged between 19 and $21 \mathrm{~m}$ for the replicates encompassed by this study (Pitt and Lanteigne 2008).

In September 2008, following the ninth sequential measurement of the study's PSPs, three of the six replicate blocks were clearcut harvested using a cut-to-length system. Harvester instrumentation permitted the spatial quantification of product volume (studwood, random-length sawlogs, pulpwood and unmerchantable discard for excessive rot or other defect) for each of more than 13000 harvested stems (Plamondon and Pitt 2013). This large data set was used to construct functions predicting product volumes from tree diameter at breast height

Table 1. Model input values for baseline economic comparison of silvicultural scenarios

\begin{tabular}{|c|c|c|c|}
\hline Cost factors & Baseline & Units & $\begin{array}{l}\text { Sensitivity } \\
\text { range tested }\end{array}$ \\
\hline Vegetation management (VM, or "brush control") & 120 & $\$ /$ ha & $\pm 50 \%$ \\
\hline Age of vegetation management & 4 & years & not varied \\
\hline Precommercial Thinning (PCT) & 650 & $\$ /$ ha & $\pm 50 \%$ \\
\hline Age of PCT & $8^{\mathrm{a}}$ & years & not varied \\
\hline Discount rate $(i)$, net of inflation & 4.0 & $\%$ & $0 \%$ through $11 \%$ \\
\hline Operational overheads & 5 & $\$ / \mathrm{m}^{3}$ & not varied \\
\hline Haul distance & 100 & $\mathrm{~km}$ & not varied \\
\hline $\begin{array}{l}\text { Change in site productivity } \\
(0=\text { observed Green River GMV) }\end{array}$ & 0 & $\%$ & $-30 \%$ to $+10 \%$ \\
\hline \multicolumn{4}{|l|}{ Revenue factors } \\
\hline Stumpage (standing timber) - Sawlog & $20.59^{\mathrm{b}}$ & $\$ / \mathrm{m}^{3}$ & $\pm 50 \%$ \\
\hline - Softwood pulpwood & $11.83^{\mathrm{b}}$ & $\$ / \mathrm{m}^{3}$ & $\pm 50 \%$ \\
\hline
\end{tabular}

a Our spreadsheet model includes simple modifiers that increase stem decay losses with stand age at the time of thinning and stand age at the time of harvest. Specific details can be found in the model documentation.

${ }^{\mathrm{b}}$ New Brunswick rate, averaged between April 1, 2000 to March 31, 2010 (Office of the Attorney General 2009). 
$(D B H)$ (Pitt et al. 2013b), which were subsequently used to estimate roundwood products across the study's 48 PSP measurement sets through time, under the assumption that these functions, based on tree size, are generally independent of tree age.

During harvest, detailed sampling was conducted to assess the incidence and severity of root and butt rot. Rot volumes were quantified and equations generated to estimate these values as a function of PCT treatment and tree DBH (Warren et al. 2013). These functions were used to quantify per-hectare losses, based on the treatment-specific diameter distributions present.

To quantify product volume and quality, 150 trees were selected from the three harvest blocks, representing the range of stem diameters present in each treatment plot (Duchesne et al. 2013). These trees produced 479 sawlogs that were converted to dimensional lumber in a manner that allowed the tracking of each tree and the treatment plot from which it originated. Lumber production values were modeled as a function of $\mathrm{DBH}$ and expressed on a per-hectare basis using the treatment-specific diameter distributions present. The resulting chips and stem tops were subjected to pulping trials for the production of Northern Bleached Softwood Kraft (NBSK) ${ }^{1}$ pulp, based on the underlying experimental design ( 4 treatments $\times 3$ blocks; Bicho et al. 2013). Pulp values were expanded to a per-hectare basis from treatment-specific estimates of slab-wood chip and top-log volumes.

The above relationships were then integrated into a spreadsheet-based model that describes stand growth and the availability of studwood, random-length sawlogs, pulpwood, and the resultant lumber and NBSK products as a function of stand age. Of the three PCT spacings tested at Green River, we limited this effort to the nominal spacing of $6 \mathrm{ft}(1600$ merchantable stems per ha by stand age 30), consistent with recommendations of Pitt et al. (2013b), Duchesne et al. (2013), Bicho et al. (2013) and Warren et al. (2013) that this spacing was near optimal for maximizing individual stem size without compromising per-hectare production or product quality. Herein, we subsequently refer to this treatment as "PCT".

Additionally, it must be recognized that the relatively fully stocked, pure conifer state of the "unthinned" stands in the Green River study would seldom be achieved on such productive sites without some VM to reduce the competitive influence of deciduous tree and shrub species (Pitt et al. 2013b). Indeed, early establishment reports for this study refer to the "brush control" that was undertaken in the unthinned plots for this purpose (Baskerville 1959, 1961; Akerley 1961). Had some plots at Green River been left fully untended (i.e., without any VM or PCT), one might expect these stands to have developed with substantially reduced conifer stocking, very likely in exchange for intolerant hardwoods (Pitt et al. 2004). At a nearby study site, for example, where neither VM nor PCT were carried out, age- 40 conifer abundance was reduced to less than half in favor of intolerant hardwoods (Olson et al. 2012). In keeping with the recognition that the unthinned stands at Green River were subjected to vegetation management (as opposed to being "untended"), we subsequently refer to this treatment herein as "VM".

\footnotetext{
${ }^{1}$ Thermomechanical pulp numbers were generated and included in the model, but not used in these analyses since greater value is currently generated with NBSK than newsprint.
}

\section{Cost factors considered}

In our spreadsheet model, only those silvicultural costs associated with stand establishment-PCT or VM-are considered directly in the valuation of standing timber (Fig. 1). A natural regeneration scenario is assumed, typical of the succession that takes place in balsam fir-dominated stands of the Northeast region (Pitt et al. 2013a). For a baseline scenario, we initialized silvicultural rates at $\$ 120 /$ ha for VM, incurred at stand age 4 , and $\$ 650 /$ ha for PCT, incurred at stand age 8 (Table 1 ). We also assumed that undesirable species would be removed during PCT, negating the additional cost of VM in these stands (note that if VM were to be applied to a stand destined for thinning, doing so would likely reduce PCT costs by an equivalent amount, retaining total input costs at around \$650/ha for the thinned stands).

Costs such as operational overheads, harvesting (felling and forwarding), lumber conversion and pulping are considered insofar as their potential to influence a buyer's willingness to pay (WTP) a premium for standing timber originating from PCT. For each of these costs, we calculated the cost difference observed between VM and PCT stands, on a per-cubic-metre basis, and then ascribed the net decrease (or increase) in costs to the PCT volume produced (Fig. 1).

Specifically, overheads (road construction and maintenance related to harvest [excluding permanent road infrastructure], and supervision [but not forest management planning]) are typically levied on the basis of the volume harvested $\left(\$ / \mathrm{m}^{3}\right)$. We initialized these overhead charges at $\$ 5 / \mathrm{m}^{3}$ for VM stands. Because PCT stands produce more merchantable volume per unit area than VM stands (Fig. 2), the associated costs may be spread over larger volumes. For example, if $20 \%$ more volume is produced in a PCT stand than a VM stand (Pitt et al. 2013b), then the construction costs of harvest-block roads will be $20 \%$ lower per $\mathrm{m}^{3}$ of wood harvested than they would in a VM stand (alternatively, to harvest a fixed volume, one would have to build $20 \%$ less road in a PCT stand). To account for this cost differential, we used:

$$
\text { [1] } \Delta O H_{r}=O H_{V M}-O H_{V M} \times\left(G M V_{V M_{r}} / G M V_{P C T_{r}}\right) \text {, }
$$

where $\Delta O H_{r}$ is the estimated overhead cost differential for PCT stands per $\mathrm{m}^{3}$ of gross merchantable volume (GMV) harvested at stand age $r$ years. For example, at a harvest age of 45 years, overhead charges in PCT stands would be $\$ 0.97 / \mathrm{m}^{3}$ lower than in an equivalent unthinned stand.

Similarly, the harvest cost functions generated from detailed timing studies on all three Green River blocks (Plamondon and Pitt 2013) indicated the following:

[2]

$\Delta H C_{r}=64.79 \times \exp (-0.0298 \times r)-51.96 \times \exp (-0.0317 \times r)$,

where $\Delta \mathrm{HC}_{r}$ is the estimated harvesting cost differential for PCT stands per $\mathrm{m}^{3}$ of gross merchantable volume harvested at stand age $r$ years. For example, at a harvest age of 45 years, wood in PCT stands was observed to be nearly $\$ 4.50 / \mathrm{m}^{3}$ less expensive to harvest than that in an equivalent unthinned stand.

External 3-D laser scans (Comact Equipment Inc.) of the 150 trees harvested for lumber conversion analysis in the Green River Study (Duchesne et al. 2013) were used within 
Basic Net Present Value calculation for standing timber:

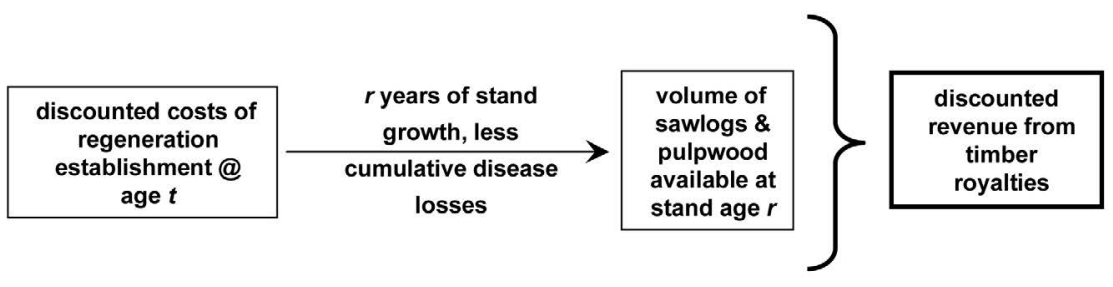

Additional willingness to pay for standing timber that has been PCT'd:

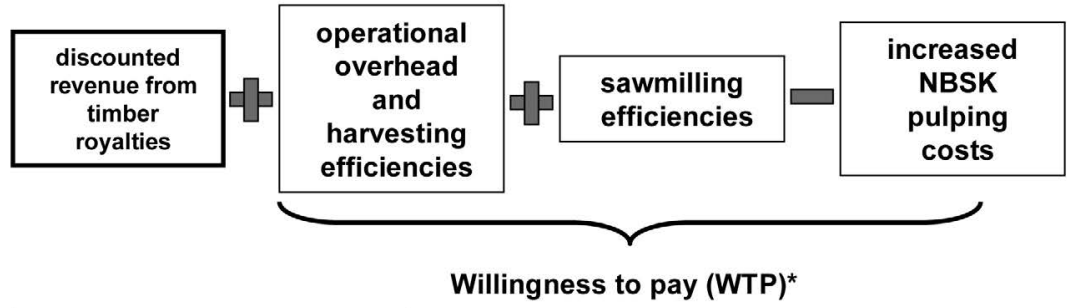

*Calculated on a per $\mathrm{m}^{3}$ basis, from observed cost differences between VM and PCT stands. Haul distances are assumed to be constant, affecting VM and PCT equally.

Fig. 1. Schematic diagram of the costs and revenues considered in the calculation of landowner Net Present Value (NPV) over the length of a rotation ( $r$ ).

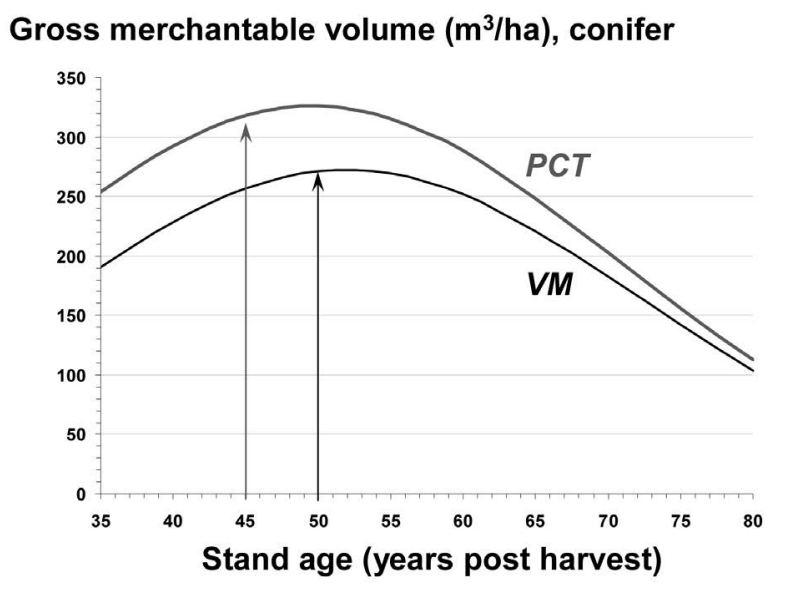

Fig. 2. Yield curves used as the foundation for economic analyses. The $x$-axis (Stand age) reflects years post harvest; since trees existed as advanced regeneration prior to harvest, actual tree ages averaged eight years older than $x$. Curves for precommercial thinning (PCT) and vegetation management (VM) scenarios are from model [A3] of Pitt et al. 2013b, formerly referred to as "6-ft spacing" and "unthinned", respectively. Arrows reflect the ages of maximum sawlog production (MAl) and the point at which the two scenarios are compared in the text.

FPOptitek to simulate the sawmilling process and estimate generic lumber conversion costs, which included variable costs related to sawing, drying and planning, but excluded fixed costs). We assumed a typical stud mill equipped with two sawing lines, having a consumption factor of $3.48 \mathrm{~m}^{3} / \mathrm{Mfbm}$ (Pierre Bédard, FPInnovations, personal communication, January 16, 2013). Simulations were run for each tree and the estimated lumber conversion costs per $\mathrm{m}^{3}$ of sawlog volume were plotted over tree size $(D B H)$. The resulting data were subjected to non-linear regression to estimate the cost functions for logs from brushed-unthinned and 6-ft spaced trees. Although there was no statistical difference between the milling costs $(M C)$ of trees coming from the two groups $(p=$ $0.20), M C$ per $\mathrm{m}^{3}$ were slightly higher for thinned trees of the same $D B H$, consistent with their slightly increased taper (Pitt and Lanteigne 2008). However, since tree sizes were consistently larger in thinned stands, the cost differential could be expressed as:
[3] $\Delta M C_{r}=211.2 \times q D B H_{V M}^{-0.7314}-282.4 \times q D B H_{P C T}^{-0.8150}$,

where $\triangle M C_{r}$ is the estimated sawmilling cost differential for PCT stands, per $\mathrm{m}^{3}$ of total sawlog volume harvested at stand age $r$ years, and $q D B H$ is the quadratic mean $D B H$ of the stands at age $r$. For example, at a harvest age of 45 years, saw timber from PCT stands was estimated to be nearly $\$ 1.70 / \mathrm{m}^{3}$ less expensive to mill than that from an equivalent unthinned stand, given differences observed in average tree size (Pitt et al. 2013 b).

Finally, pulping of the sawmill residues (slab-wood) and pulpwood (top-logs) emanating from the sawmilling trials generated treatment-specific data that permitted costing of the production of NBSK. The differential in profit margins for the production of NBSK from PCT stands was calculated as $-\$ 6.27 /$ tonne for tops and $+\$ 0.84 /$ tonne for slabs (Bicho et al. 2013). Translating the observed $\mathrm{m}^{3}$ per ha production of top-log and slab-wood chips to NBSK product allowed valuation of this differential on a per-hectare basis. For example, by stand age 45 , PCT'd stands produced $43.4 \mathrm{~m}^{3} /$ ha of top-log wood and 120.4 $\mathrm{m}^{3} /$ ha of slab-wood, each producing 5.6 tonnes/ha and 15.0 tonnes/ha of NBSK product, respectively. Given the differential profit margins identified, this suggests that, from a pulp production perspective, PCT stands might be valued as much as $\$ 22.51 /$ ha less than unthinned stands of the same age.

While the distance between standing timber and a processing facility may significantly affect the value of standing timber through a buyer's willingness to pay, we assumed that transportation costs apply to wood from thinned and unthinned stands in an equitable fashion. In the model, transportation costs (TC) per $\mathrm{m}^{3}$ are estimated as a linear function of haul distance $(H D$, 
$\mathrm{km}$ ) and $G M V\left(\mathrm{~m}^{3}\right)$, irrespective of treatment ("Log Truck Costing Model”, Jan.Michaelsen@fpinnovations.ca):

$$
\text { [4] } T C=[2.958+0.0728 \times H D] \times G M V \text {. }
$$

Accordingly, our spreadsheet allows the user to estimate wood costs under different haul distances, but for the purposes herein, we have fixed this distance at $100 \mathrm{~km}$.

\section{Benefit values considered}

Timber Royalties (a.k.a. Crown Dues) are the "values" that we ascribed to standing timber resulting from the treatments tested at Green River. As a baseline, the averaged rates published for New Brunswick for the period April 1, 2000, to March 31, 2010 (Office of the Attorney General 2009) were used: $\$ 11.83 / \mathrm{m}^{3}$ for pulpwood; $\$ 20.59 / \mathrm{m}^{3}$ for studwood and random-length sawlogs (Table 1). For example, a stand thinned to 6-ft spacing was observed to contain a total of $311 \mathrm{~m}^{3} /$ ha, distributed as $268 \mathrm{~m}^{3}$ of sawlogs and $43 \mathrm{~m}^{3}$ of pulpwood per ha at stand age 45 (Pitt et al.2013b), generating a total stumpage value of just over $\$ 6000 /$ ha.

Additionally, we calculated the theoretical premium that a buyer might pay for standing timber that has originated from a PCT treatment (Fig. 1) by adding the cost differentials (VM - PCT; calculated above through [1], [2], and [3]) for overhead charges, harvesting, sawmilling and pulping. Continuing with the above example, the value of a 45-year-old PCT stand might then be $\$ 6000 /$ ha, plus a willingness-to-pay valued at $\left(\$ 0.97\left[311 \mathrm{~m}^{3} / \mathrm{ha}\right]+\$ 4.50\left[311 \mathrm{~m}^{3} / \mathrm{ha}\right]+\$ 1.70\left[268 \mathrm{~m}^{3} / \mathrm{ha}\right]-\right.$ $\$ 22.51 / \mathrm{ha})=\$ 2134 / \mathrm{ha}$.

\section{Economic analyses}

The costs and benefits identified above were then contrasted in discounted form using:

$$
N P V=\frac{\sum_{i=0}^{r} R_{t}(1+i)^{r-t}-\sum_{i=0}^{r} C_{t}(1+i)^{r-t}}{(1+i)^{r}}
$$

where $N P V$ is the Net Present Value (\$/ha), $t$ is the time (years) when a cost or revenue is incurred ( $t=0$ is the present), $r$ is the rotation age (years), $R_{t}$ is revenue incurred at time $t$; $C_{t}$ is cost incurred at time $t$, and $i$ is the discount rate, net of inflation (Gregory 1972). In the analyses reported herein, we used costs and prices in relatively recent dollar values (as described above) to calculate net worth, with $i$ being initialized at $4 \%$ (intended to be a real interest rate, net of inflation) (Table 1). The internal rate of return (IRR) was calculated for VM, PCT, and PCT+WTP scenarios, as the value of $i$ for which discounted costs equal discounted revenues.

As a baseline, the NPV analysis was conducted with the initial inputs outlined above and detailed in Table 1 . The sensitivity of this outcome was then observed in response to our varying certain key parameters. Specifically, discount rate was varied from $0 \%$ through $11 \%$. The effects of site productivity were observed by suppressing the Green River yield curves (Fig. 2) by as much as $30 \%$, and inflating them by as much as $10 \%$. The costs of VM and PCT were simultaneously varied through $\pm 50 \%$ of the baseline values. Timber royalties for sawlogs and pulpwood were each varied through $\pm 50 \%$ of the baseline values. Parameter interactions were not studied.

\section{Results and Discussion}

In an economic analysis of long-term investments, such as those in silviculture, selection of an appropriate age at which to compare alternatives can be difficult. A key conclusion of the work of Duchesne et al. (2013) and Bicho et al. (2013) was that there were no substantive differences between PCT and VM in terms of end-product quality. Any economic comparisons made using the data from this experiment should take place at stand ages that reasonably support this conclusion, or they may not be valid. In addition, foresters often have the forest-level mandate to "maximize production" to meet sustainability objectives. As a means of addressing both of these criteria, we selected the age of maximum sawlog volume mean annual increment (MAI), which occurred at stand ages 45 $\left(5.9 \mathrm{~m}^{3} / \mathrm{ha} / \mathrm{yr}\right)$ and $50\left(4.3 \mathrm{~m}^{3} / \mathrm{ha} / \mathrm{yr}\right)$ for the PCT and VM treatments, respectively (Pitt et al. 2013b; illustrated on the gross merchantable volume curves of Fig. 2). Unless otherwise specified, all subsequent comparisons of silvicultural scenarios herein have been made at these ages.

Given the initial inputs summarized in Table 1, the Green River data suggest that PCT treatment would generate a landowner NPV of $\$ 560 /$ ha at the point of maximum sawlog MAI (Fig. 3), with an IRR of $6.2 \%$. Contrasted with a NPV of $\$ 600 /$ ha (IRR $=8.5 \%)$ for VM, the results suggest that both treatments would lead to stands of approximately similar value in terms of timber royalties. Both PCT and VM results closely match the financial analyses conducted on growth projections for a similar study in fir-spruce stands of central Maine (Daggett 2003, Bataineh et al. 2013). For VM, our IRR is higher than the $4.3 \%$ estimated on growth projections by Homagain et al. (2011) for a variety of boreal species in Ontario, possibly due to the wide range of site conditions that they considered.

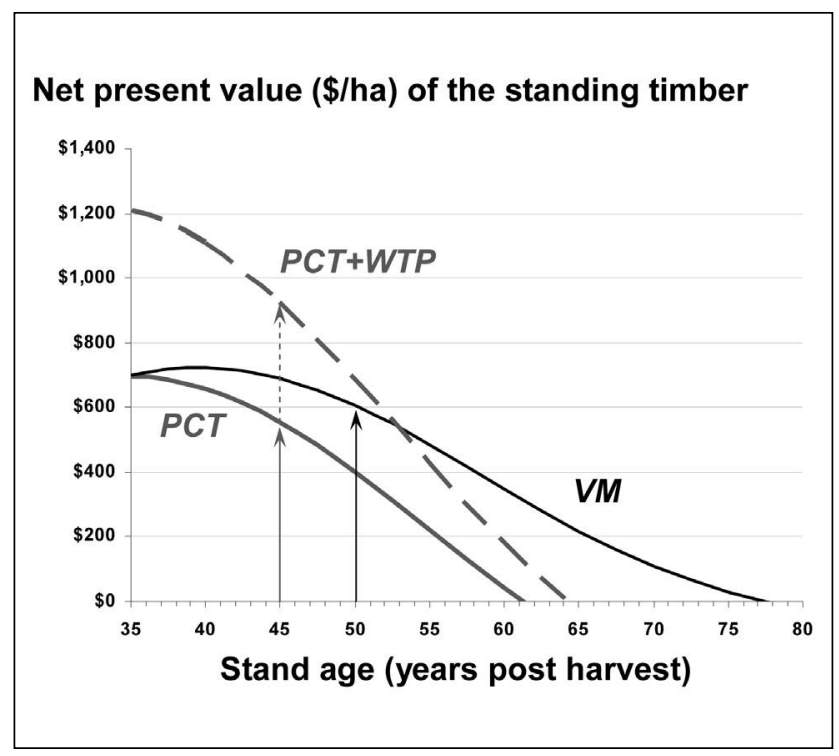

Fig. 3. Net present value (NPV) for silvicultural scenarios involving precommercial thinning (PCT) and vegetation management (VM), as a function of stand age, given the baseline context outlined in Table 1. Value propositions based on timber royalties are shown as solid lines; the dashed line reflects the theoretical value of standing timber based on buyer's willingness to pay (WTP) a premium for wood from thinned stands. Arrows reflect the ages of maximum sawlog production (MAl) and the point at which the scenarios are compared in the text. 


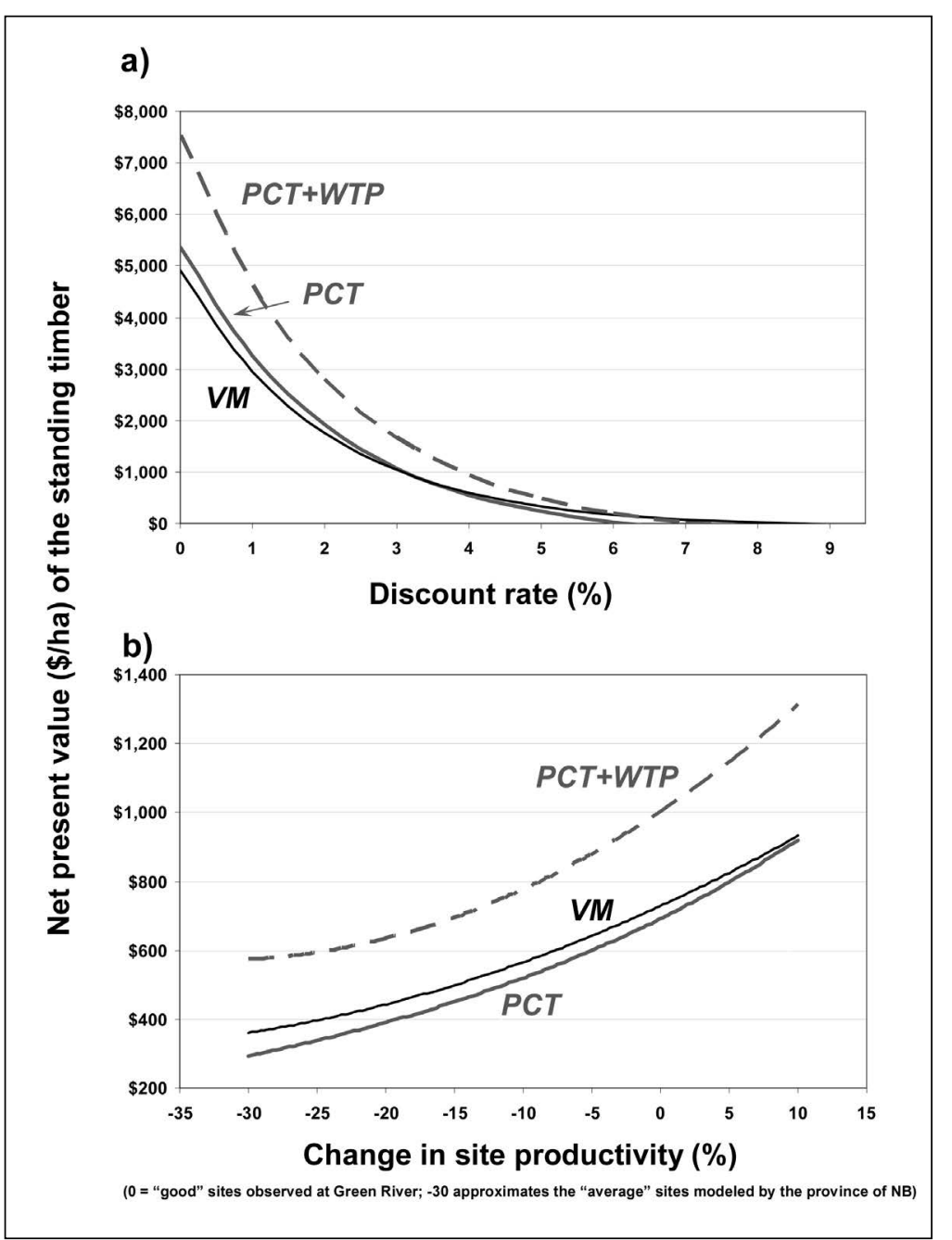

Fig. 4. Net present value (NPV) for silvicultural scenarios involving precommercial thinning (PCT) and vegetation management (VM), as a function of (a) discount rate $(i)$ and $(b)$ changes in site productivity, given all other conditions held constant at the baseline outlined in Table 1. Value propositions based on timber royalties are shown as solid lines; the dashed line reflects the theoretical value of standing timber based on buyer's willingness to pay (WTP) a premium for wood from thinned stands.

If buyers are willing to pay a premium for the increased efficiencies of harvesting and milling wood from PCT stands, potentially greater stand values might be realized ( $\$ 930 / \mathrm{ha}$; IRR=7.1\%) through PCT (despite these stands being slightly less attractive for pulping) (Fig. 3). Under such market conditions, landowners may expect to realize as much as $53 \%$ more value for stands that have been subjected to $\mathrm{PCT}$, as opposed to VM alone. It is important to note, however, that the slopes of these NPV curves suggest that the greater the silvicultural investment, the more narrow the window of opportunity for harvest prior to reaching the economic "best-before" date. In other words, stands with high silviculture investment have a more narrow "optimum rotation age" than those with low silvicultural investment.

\section{Discount rate}

Time preference for money (discount rate) has a profound effect on the NPV of silvicultural options. As discount rates are increased, the age of financial maturity (maximum NPV) will fall, regardless of the silvicultural scenario being considered. For example, if one had very low time preference for money ( $i \sim 1 \%)$, maximum landowner NPV would occur at stand ages near 50 and 55 for the PCT and VM treatments, respectively. At a discount rate of about $2 \%$, the financial maturity of these silviculture scenarios would approximately coincide with the ages at which we observed maximum sawlog production to occur (45 and 50, as mentioned above). As discount rates in excess of $2 \%$ are considered, financial maturity occurs at increasingly younger ages. Again, we caution that the wood quality statistics reported for this study (Bicho et al. 2013, Duchesne et al. 2013) would very likely not apply to stand ages much below 45 years and the financial optima suggested by these analyses may therefore be misleading.

As has been shown with other financial analyses of silvicultural investment (e.g., Rollins et al. 1995, Hawkins et al. 2006), landowner NPV is highly influenced by the discount rate (i) used in the calculation (Fig. 4a). Clearly, the financial advantage of improved merchantable volumes and sawlog volumes stemming from PCT decreases dramatically as $i$ is increased. If compensated strictly by timber royalties, landowners might be encouraged to undertake VM through discount rates as high as $8.5 \%$ (the IRR for this treatment), all other elements of the baseline scenario being held constant (Table 1). Beyond discount rates of about $3.5 \%$, PCT appears to not offer any economic advantage over VM, unless buyers are willing to pay a premium for thinned stands, in which case PCT offers advantages over VM through rates as high as $6 \%$.

The appropriate discount rate for comparing silvicultural scenarios has long been a topic of debate. Rates of 3\% to $4.5 \%$ may approximate what is termed the social discount rate, or a government's time preference for achieving public policy objectives (Davis 1966, Klemperer et al. 1994, Hawkins et al. 2006); we chose our baseline scenario to fall within this range. It has been argued that higher rates approximate historical opportunity costs for capital in the private sector. Alternatively, there are situations where forest managers of very large forests may treat regeneration costs as current costs, similar to logging, and not subject them to interest accumulation over the rotation (Shepard 1925, Marty 1975, Reed and Baskerville 2001). In addition, decision-making on large forests is often influenced by non-timber values that are difficult to quantify in economic terms (New Brunswick Crown Lands Task Force 2011). Clearly, landowners/managers will have their own particular perspectives with respect to time preference and there is no single discount rate that correctly addresses all needs.

\section{Site Productivity}

The Green River experimental sites are considered to be "very good" sites for balsam fir (site indices between 19 and 21; Pitt and Lanteigne 2008). There is little question that the NPVs 


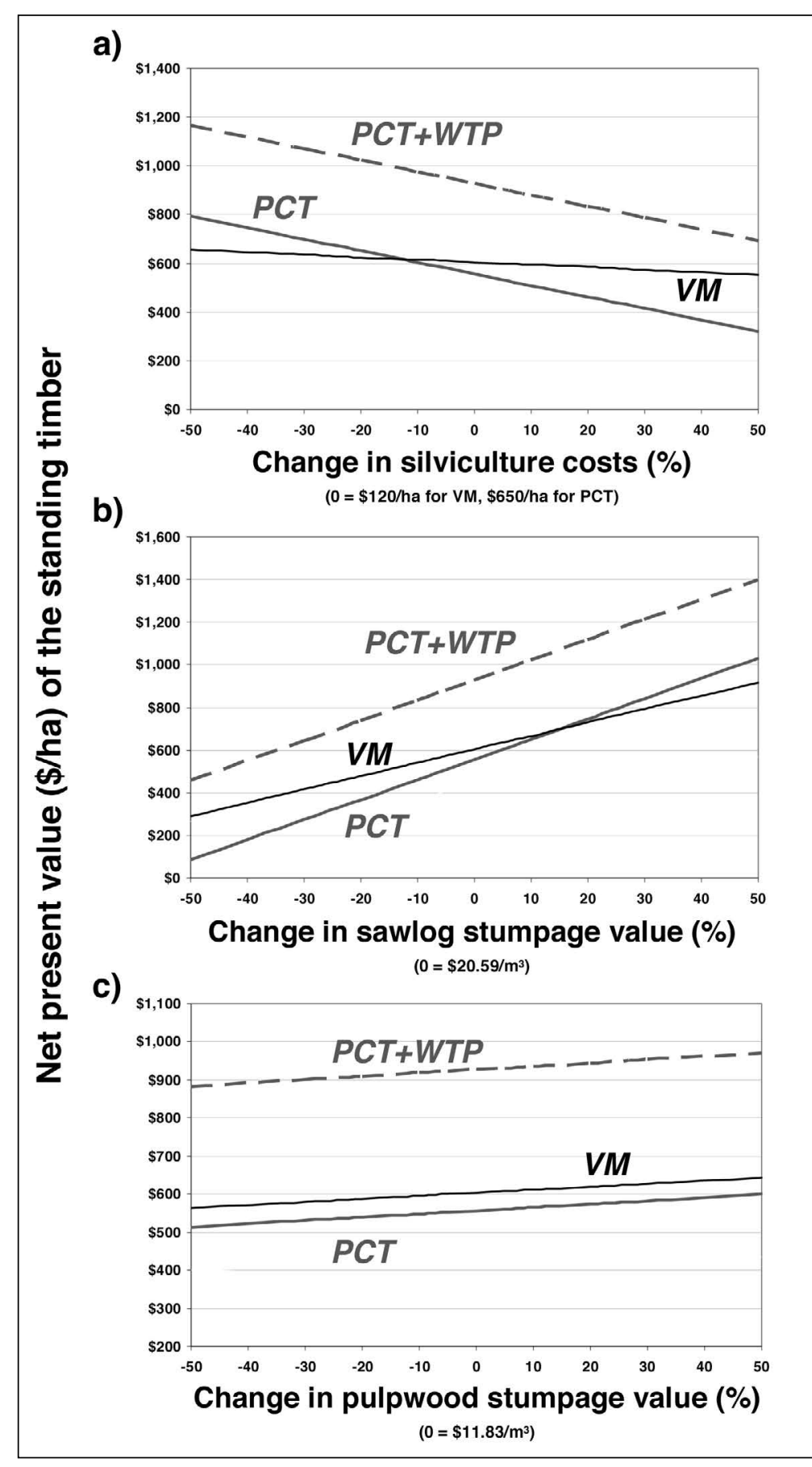

Fig. 5. Net present value (NPV) for silvicultural scenarios involving precommercial thinning (PCT) and vegetation management (VM), as a function of changes in (a) silviculture costs, (b) sawlog stumpage value and (c) pulpwood stumpage value, given all other conditions held constant at the baseline outlined in Table 1. Value propositions based on timber royalties are shown as solid lines; the dashed line reflects the theoretical value of standing timber based on buyer's willingness to pay (WTP) a premium for wood from thinned stands. match those used for natural spruce-fir stands (thinned and unthinned) by the province of New Brunswick in the current forest management plan for the Green River area $\left(r^{2}>0.98\right)$ (data provided by Adam Dick, New Brunswick Growth and Yield Unit, December 9, 2011). These provincial curves were derived from a large number of sample plots reflecting a wide range of sites and are considered to represent an "average" site condition for the region. The ages of maximum sawlog production occur for these curves at $45\left(4.3 \mathrm{~m}^{3} / \mathrm{ha} / \mathrm{yr}\right)$ and 50 $\left(2.7 \mathrm{~m}^{3} / \mathrm{ha} / \mathrm{yr}\right)$ for the PCT and VM scenarios, respectively. At these ages, PCT generates \$260/ha of landowner NPV based on timber royalties; about $21 \%$ less than may be realized through VM alone (\$330/ha) (Fig. 4b). The IRR of the PCT treatment is $5.3 \%$, compared to $7.3 \%$ for VM. However, if the landowner can attract a premium for managedstand stumpage, NPVs could increase to $\$ 551 /$ ha (6.2\%) following PCT. Thus, even with a $30 \%$ reduction in the yields observed in the Green River experiment, there may be financial advantages to PCT, given all other inputs outlined in Table 1.

However, the results illustrated in Fig. 4b clearly suggest that relatively small changes in site productivity may result in large changes in NPV, particularly as one moves away from the "good sites" observed at Green River. For example, the data suggest that a $5 \%$ reduction in site productivity will result in a $10 \%$ reduction in landowner NPV, regardless of the silvicultural scenario considered. Since silviculture dollars are invariably limited, these results underscore the fact that value is ultimately maximized by investing on the best sites available.

\section{Silviculture costs}

As is often touted, the costs of silviculture can significantly influence landowner NPV (Fig. 5a). For example, as PCT costs range from $\$ 325 /$ ha to $\$ 975 /$ ha (\$650/ha $\pm 50 \%$ ), NPV falls from $\$ 794$ / ha to $\$ 319 /$ ha $( \pm 43 \%)$, if all other inputs are held at baseline levels (Table 1). Similar percentage changes in VM costs do not influence NPVs as dramatically ( $\$ 120 /$ ha $\pm 50 \%$ translate to NPVs ranging from $\$ 656 /$ ha to $\$ 553 / \mathrm{ha}$, or $\pm 8 \%$ ). When the costs of PCT exceed about $\$ 585 /$ ha $(i=4 \%)$, landowners would be unlikely to thin unless they are receiving a premium for their thinned stands at the time of sale. Under this willingness-to-pay scenario, PCT appears to offer favourable returns through silviculture cost increases in excess of $50 \%$ of the baseline values ( $>\$ 975 /$ ha for PCT and $>\$ 180 /$ ha for VM). generated by the baseline scenario (Table 1), are sensitive to the yield assumptions derived from the Green River data (Fig. 2), as indicated by the residual value chain NPVs plotted through changes in site productivity (Fig. 4b).

If the yield curves generated from the Green River data (PCT and VM; Fig. 2) are suppressed by about $30 \%$, they very closely
Timber royalty prices

In many jurisdictions, posted royalty rates for sawlogs and pulpwood dictate the direct revenue received by a landowner in exchange for the right to harvest wood. Because PCT and VM produce different proportions of these two roundwood products, the landowner value propositions illustrated in Figures 3 to 5 are heavily influenced by the preferential values ascribed 
to sawlogs (Table 1). For example, as sawlog rates range from $\$ 10.30 / \mathrm{m}^{3}$ to $\$ 30.89 / \mathrm{m}^{3}\left(\$ 20.59 / \mathrm{m}^{3} \pm 50 \%\right)$, landowner NPV following PCT increases from $\$ 85 /$ ha to more than $\$ 1000 /$ ha $( \pm 85 \%)$, if all other inputs are held at baseline levels (Fig. 5b). Such changes do not affect NPVs following VM quite as severely, due to the smaller proportion of sawlogs generated (NPV = $\$ 291 /$ ha to $\$ 918 /$ ha, or $\pm 51 \%$ ). As sawlog rates fall below about $\$ 22 / \mathrm{m}^{3}$, landowners would be unlikely to thin unless they are receiving a premium for their thinned stands at the time of sale $(i=4 \%)$.

One can argue that negotiated stumpage values should reflect different sizes of logs (e.g., random-length vs. studwood). Thinned stands contained nearly twice the volume of randomlength sawlogs observed in VM stands $(p=0.01)$ and, as such, a landowner might realize an additional $5 \%$ to $10 \%$ increase in NPV from these stands, depending on the premium offered.

Not surprisingly, the effects of changes in pulpwood royalties have a much less dramatic effect on landowner NPV than changes in sawlog royalties (Fig. 5c). This is due to the relatively small proportion of pulpwood volume present in these stands (Pitt et al. 2013b).

Of course, the overall value of timber royalties has a direct influence on landowner NPV and can significantly influence the attractiveness of any silvicultural investment. If, for example, we apply the 10-year average Crown dues for the province of Ontario $^{2}$ to these analyses (all other inputs held at the baselines in Table 1), a landowner would likely just break even thinning unless a willingness to pay exists, in which case NPV $=\$ 384 /$ ha $(58 \%$ less than the same landowner would receive in New Brunswick). There is a plethora of factors considered in the establishment of Crown stumpage rates across the country and we do not wish to delve into the argument of whether or not rates are sufficient to encourage silvicultural investment. However, when circumstances lead to stumpage prices that are less than market value, treatments such as PCT and VM must be valued by some means other than a NPV calculation.

\section{Summary and Implications for Management}

In northeastern Canada there are precious few rotation-length examples of the growing capacity of high-quality forest sites under managed conditions (full stocking to desired species with density regulation). The Green River precommercial thinning trial, established by Dr. Gordon Baskerville in northwestern New Brunswick in 1959, offers a rare, statistically rigorous view of the effects of precommercial thinning and brush control on the growth, yield and value of balsam fir dominated stands through an entire rotation. Economic analyses of these rotation-length data suggest that silvicultural investments such as precommercial thinning and vegetation management on "prime sites" (highly productive sites situated in close proximity to wood processing infrastructure) can make financial sense, given reasonable assumptions around future costs and benefits, despite the long-term nature of these investments.

We recognize that there are many different types of landowners and forest managers, each with their own unique objectives and constraints. To some, our stand-level economic analyses will seem overly simplistic in the sense that there are many worthwhile benefits provided by PCT and vegetation

\footnotetext{
${ }^{2}$ Averaged between April 1, 2000, to March 31, 2010, including base stumpage and charges for forest inventory, Forest Futures Trust, and Forest Renewal Trust.
}

management that have not been accounted for in these analyses. For example, we have not considered the potentially significant downstream economic significance of constant wood flow, enabled by moving stands ahead in a harvest queue (Reed and Baskerville 2001). We have not considered the intermediate revenues that could be generated through commercial thinning, an activity that will likely take place mid-rotation in many PCT stands. Similarly, we have not quantified the many potential non-timber benefits valued by Canadians, such as increased size and number of protected areas, recreational opportunities and wildlife habitat (e.g., Homyack et al. 2004), which may accrue as a result of the increased yield and stand structure changes incurred by thinning and vegetation management. Carbon sequestration is a non-timber issue of growing concern; a recent analysis of greenhouse gas emissions from a New Brunswick forest products company revealed the importance of increasing the forest products pool in sequestering more atmospheric carbon, facilitated through more intensive silviculture (Cameron et al. 2013). Clearly, when considering treatments such as PCT and VM, forest managers must often weigh a variety of costs and benefits that are difficult to incorporate into simple calculations of NPV.

Moreover, decisions that affect the management of very large forests in Canada must potentially be made with a view that extends beyond value creation by the "landowner". The lumber (Duchesne et al. 2013) and pulp (Bicho et al. 2013) product values generated by the Green River treatments, for example, can be incorporated in the calculation of NPV, not to assess the value of standing timber to a landowner, but to estimate the value that the standing timber may contribute to the sector as a whole (Fig. 6). It is clear from this perspective that thinning and vegetation management offer significant potential to increase sector

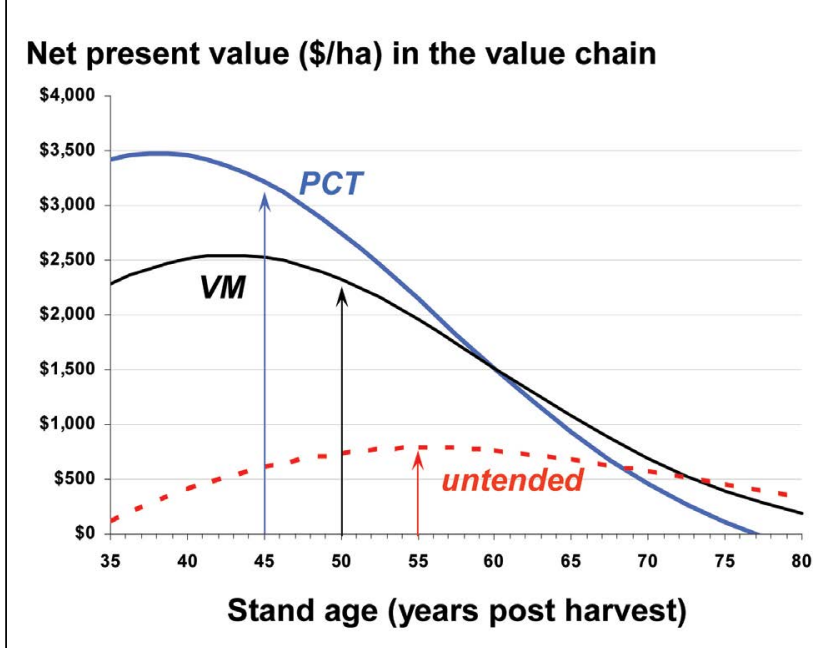

Fig. 6. Theoretical net present value (NPV) available for stumpage, profit and risk across the value chain. In contrast to Fig. 3 , these curves do not reflect the value accrued to the landowner or entity that has invested in VM or PCT; they are intended to show the value that the standing timber may contribute to the sector as a whole. The red dashed line indicates what might accrue through extensive, low-cost silviculture, assuming the same total volume generated by VM, but distributed as $60 \%$ conifer $-40 \%$ intolerant hardwood, with a 10 year lag in the yield curve. All other conditions have been held constant at the baselines outlined in Table 1. 
value along the value chain. This is particularly obvious when one compares the value contributed by thinning and vegetation management to what might theoretically accrue through extensive, low-cost silviculture. Such a comparison suggests that low levels of silvicultural investment could have long-term negative impacts on future timber supply and, concomitantly, the socioeconomic well-being of rural communities dependent upon a sustainable forest resource (Auditor General of Ontario 2011, New Brunswick Crown Lands Task Force 2011).

Despite our not accounting for many of the ancillary benefits associated with PCT, our analyses of the rotation-length Green River data suggest that modest investment in thinning and vegetation management on the right sites may generate, through a fairly wide array of economic circumstances, increased landowner timber revenues, which could ultimately contribute to a healthier forest sector. We hope that we have done justice to the efforts of Baskerville and his colleagues in providing forest managers with these analyses to use as a guide in choosing a silviculture regime that will sustainably maximize economic benefits in their forests. As more rotation-length data become available for Canadian growing conditions, it would be useful to evaluate other silvicultural interventions, such as planting, genetic improvement and commercial thinning, in a similar fashion.

\section{Acknowledgements}

Considerable funding for this work was provided by the Canadian Wood Fibre Centre of the Canadian Forest Service. Extensive fieldwork could not have been efficiently completed without the very competent hands of James Farrell, Jeff Case, and Tony Iserhoff, Gilles Arsenault and Stephen Billingsley. Luc Ouellet and Kevin Topolniski (Acadian Timber), Gaetan Pelletier and Greg Adams (J.D. Irving Limited), and their very professional harvesting crews, collectively, provided tremendous in-kind cooperation and contribution to this new chapter in the Green River Legacy. Of course, historically, we are indebted to Dr. Gordon Baskerville for his foresight and early efforts in the sound establishment of this experiment. Fraser Papers Inc. (now Acadian Timber Corp. and Twin River Papers Inc.) and the New Brunswick Department of Natural Resources and Energy are credited with protecting these plots over the years. Finally, we owe special thanks to Bob Wagner, Greg Adams, Dan McKenney, Bernard Daigle, Sen Wang and Karen Jamieson for excellent suggestions on earlier versions of this manuscript.

\section{References}

Akerley, B.J. 1961. Establishment report - Cleaning and thinning young fir, 1961. Project M-443-59. Internal report, Department of Northern Affairs and National Resources, Forestry Branch, Maritimes District, Fredericton, NB. 29 p.

Anonymous. 2008. Management alternatives for New Brunswick's Public Forest. Report of the New Brunswick Task Force on Forest Diversity and Wood Supply. 108 pp. Available at http://www2.gnb.ca/ content/dam/gnb/Departments/nr-rn/pdf/en/CrownLandsForests/ Erdle/ErdleReport-e.pdf [Accessed 7 May 2013].

Auditor General of Ontario. 2011. Section 3.05, Forest Management Program, Ministry of Natural Resources, Ministry of Northern Development, Mines, and Forestry. pp. 127-149. [online] Available at http:// www.auditor.on.ca [Accessed 8 January 2013].

Baskerville, G.L. 1959. Establishment report - Cleaning and thinning young fir, 1959 Project. M-443-59. Internal report, Department of Northern Affairs and National Resources, Forestry Branch, Maritimes District, Fredericton, NB. 28 p.
Baskerville, G.L. 1961. Establishment report - Cleaning and thinning young fir, 1960. Project M-443-59. Internal report, Department of Northern Affairs and National Resources, Forestry Branch, Maritimes District, Fredericton, NB. 5 p.

Bataineh, M.M., R.G. Wagner and A.R. Weiskittel. 2013. Long-term response of spruce-fir stands to herbicide and precommercial thinning: Observed and projected growth, yield, and financial returns in central Maine, USA. Can. J. For. Res. 43(999): 385-395

Bicho, P., E. Portillo, B. Yuen, D. Yan and D.G. Pitt. 2013. Effects of precommercial thinning on the forest value chain in northwestern New Brunswick: Part 5 - Kraft and Thermomechanical pulping and pulp quality. For. Chron. 89(4): 490-501.

Cameron, R.E., C.R. Hennigar, D.A MacLean, G.W. Adams, and T.A. Erdle. 2013. A comprehensive greenhouse gas balance for a forest company operating in northeast North America. J. For. [In press].

[CCFM] Canadian Council of Forest Ministers. 2012 . National Forestry Database, Compendium of Canadian Forestry Statistics [online]. CCFM, Ottawa, ON. Available at http://nfdp.ccfm.org [Accessed 17 December 2012].

Daggett, H. 2003. Long-term effects of herbicide and precommercial thinning treatments on species composition, stand structure, and net present value in spruce-fir stands in Maine: The Austin Pond study. M.S. Thesis. Univ. Maine, Orono, ME. 136 p.

Davis, K.P. 1966. Forest management: regulation and valuation. McGraw-Hill, NY. 519 p.

Duchesne, I., D.G. Pitt and F. Tanguay. 2013. Effects of precommercial thinning on the forest value chain in northwestern New Brunswick: Part 4 - Lumber production, quality and value. For. Chron. 89(4): 474-489.

Gregory, G.R. 1972. Forest Resource Economics. John Wiley \& Sons, NY. 548 p.

Hawkins, C.B.D, T.W. Steele and T. Letchford. 2006. The economics of site preparation and the impacts of current forest policy: evidence from central British Columbia. Can. J. For. Res. 36: 482-494.

Homagain, K., C.K. Shahi, N.J. Luckai, M. Leitch and F.W. Bell. 2011. Benefit-cost analysis of vegetation management alternatives: An Ontario case study. For. Chron. 87: 260-273.

Homyack, J.A., D.J. Harrison and W.B. Krohn. 2004. Structural differences between precommercially thinned and unthinned conifer stands. For. Ecol. Man. 194: 131-143.

Karsh, M.B., M.B. Lavigne and J.G. Donnelly. 1994. Growth response of the balsam fir and black spruce spacing trials. Nat. Resour. Can., Can. For. Serv. - Newfoundland \& Labrador Region. Inf. Rep N-X-291. 35 p

Klemperer, W.D., J.F. Cathcart, T. Häring and R.J. Alig. 1994. Risk and the discount rate in forestry. Can. J. For. Res. 24: 390-397.

Marty, R. 1975. Comprehensive analysis of public forestry project and program alternatives. J. Forestry 75: 701-704.

Murray, T.S. and M.D. Cameron (eds.) 1987. Proceedings of the precommercial thinning workshop. March 19, 1987, Fredericton, NB. Can. For. Serv. - Maritimes, Fredericton, NB. 105 p.

New Brunswick Crown Lands Task Force. 2011. A path for a sustainable economic forest in New Brunswick [online]. Province of New Brunswick, Fredericton, NB. Available at http://www2.gnb.ca/content/ dam/gnb/Departments/nr-rn/pdf/en/CrownLandsForests/ APathForASustainableEconomicForestInNB-Oct2011.pdf [Accessed 8 January 2013].

Office of the Attorney General. 2009. N.B. Acts and Regulations [online]. Queen's Printer for New Brunswick, Fredericton, NB. Available at http://www.gnb.ca/0062/acts/ [Accessed 11 December 2009].

Olson, M.G., R.G. Wagner and J.C. Brissette. 2012. Forty years of spruce-fir stand development following herbicide application and precommercial thinning in northern Maine, USA. Can. J. For. Res. 42:(1) $1-11$.

Piene, H. 1982. Timing of spacing operations young balsam fir. For. Chron. 58: 93-95. 
Pitt, D.G. and L. Lanteigne. 2008. Long-term outcome of precommercial thinning in northwestern New Brunswick: growth and yield of balsam fir and red spruce. Can. J. For. Res. 38: 592-610.

Pitt, D.G., L. Lanteigne, M.K. Hoepting and J. Farrell. 2013a. Effects of precommercial thinning on the forest value chain in northwestern New Brunswick: A fifty-year legacy of forest research continues. For. Chron. 89(4): 439-445.

Pitt, D.G., L. Lanteigne, M.K. Hoepting and J. Plamondon. 2013b. Effects of precommercial thinning on the forest value chain in northwestern New Brunswick: Part 1 - Roundwood production and stumpage value. For. Chron. 89(4): 446-457.

Pitt, D.G., M. Mihajlovich and L. Proudfoot. 2004. Juvenile stand responses and potential outcomes of conifer release efforts on Alberta's spruce-aspen mixedwood sites. For. Chron. 80(5): 583-597.

Plamondon, J. and D.G. Pitt. 2013. Effects of precommercial thinning on the forest value chain in northwestern New Brunswick: Part 2 - Efficiency gains in cut-to-length harvesting. For. Chron. 89(4): 458-463. Reed, F.L.C. 1986. Canadas timber supply - a growing concern. For. Chron. 64: 335-338.

Reed, F.L.C. and G.L Baskerville. 2001. A contemporary perspective on silvicultural investments. Western Silvicultural Contractor's Association. 15 p. Available at http:// www.wsca.ca/ [Accessed 8 January 2013].
Rollins, K., M. Forsyth, S. Bonti-Ankomah and B. Amoah. 1995. A financial analysis of a white pine improvement cut in Ontario. For. Chron. 71: 466-472.

Shepard, W. 1925. The bogey of compound interest. J. Forestry 25: 251-259.

Smith, D.M. 1986. The practice of silviculture, $8^{\text {th }}$ ed. John Wiley \& Sons Inc., NY. 572 p.

Smith, D.M., B.C. Larson, M.J. Kelty and P.M.S. Ashton. 1997. The practice of silviculture: applied forest ecology, $9^{\text {th }}$ ed. John Wiley \& Sons, Inc., Toronto. $537 \mathrm{p}$.

Warren, G., P. Baines, J. Plamondon and D.G. Pitt. 2013. Effects of precommercial thinning on the forest value chain in northwestern New Brunswick: Part 3 - Incidence of root and butt decay. For. Chron. 89(4): 464-473. 